\author{
Hanna Mizgajska \\ Dorota Plóciennik \\ Uniwersytet Ekonomiczny \\ w Poznaniu
}

\title{
Wpływ cech społeczno-demograficznych na sposób zarządzania firmą przez kobiety i mężczyzn na przykładzie Wielkopolski
}

\author{
Influence of social and demographic factors on business management methods \\ used by women and men illustrated on example of Wielkopolska region
}

\begin{abstract}
Streszczenie
Celem artykułu jest zbadanie wpływu wybranych cech społeczno-demograficznych na sposób zarządzania małą i średnią firmą przez kobiety i mężczyzn. Przez sposób zarządzania przedsiębiorstwem rozumie się: cele prowadzonej firmy, przeznaczenie zysku, korzystanie ze środków UE, kredytów i zastosowanie Internetu.

Cechy społeczno-demograficzne podzielono na czynniki związane z osobą właściciela/właścicielki oraz związane z firmą. Czynniki związane z osobą właściciela/właścicielki to: edukacja, wiek oraz sytuacja rodzinna określona przez stan cywilny i liczbę dzieci. Natomiast cechy związane z firmą to: wielkość firmy, długość lat na rynku, wielkość miasta, w którym firma funkcjonuje, oraz prowadzenie firmy rodzinnej.

Badanie wpływu wybranych cech społeczno-demograficznych poprzedzono analizą porównawczą sposobu zarządzania firmą przez kobiety i mężczyzn.

W pracy wykorzystano materiał empiryczny zebrany w sposób celowy metodą ankietową ze 143 firm kierowanych przez kobiety oraz 158 firm kierowanych przez mężczyzn reprezentujących sektor małych i średnich przedsiębiorstw w Wielkopolsce. Ankietyzacja przedsiębiorstw została przeprowadzona przez studentów I roku studiów magisterskich Uniwersytetu Ekonomicznego w Poznaniu w ramach przedmiotu przedsiębiorczość. Badania były przeprowadzone w $2011 \mathrm{r}$., a informacje o firmie i sposobach zarządzania dotyczą lat 2007-2010.

Materiał badawczy przetworzony został metodami analizy porównawczej, takimi jak: test zgodności chi-kwadrat, test t-studenta oraz test Scheffe. Natomiast przy weryfikacji merytorycznej hipotez założony został poziom istotności $\alpha=0,05$.
\end{abstract}

\footnotetext{
Abstract

The aim of this article is to examine relations between the selected social and demographic factors associated with a businessperson and the way he or she manages a small or medium-sized company. With respect to how a company is managed, it can be described by its goals, profit allocation, the use of EU funds, the credit facilities, and the Internet.

As regards the socio-demographic factors relating to a business' owner, they include education, age, marital status, and the number of children. Finally, the factors relating to a business itself include its size and a number of years on the market, the size of a city or town that the company operates in, and also whether it is a family company.

The study of relations between the aforementioned factors has been preceded by an analysis of how businesses are managed by women and men.
} 
This paper is based on the empirical material gathered by means of questionnaires in 143 companies managed by women, and 158 companies managed by men, representing the sector of small and medium enterprises in the Wielkopolska region. The questionnaires were distributed by the first-year students of a master degree programme at the Poznań University of Economics as a part of their entrepreneurship course. The research was conducted in 2011 and the collected information concerning the companies and their methods of management refers to the years 2007-2010.

The research material was analysed using the relations of quantitative and qualitative characteristics. The chi-squared test, the test of significance for two or more average values (Student's t-test), and variation analysis (Scheffé's test) were carried out. A significance level that was assumed for the content-related verification of hypotheses equalled to $\alpha=0.05$

Słowa kluczowe: cechy społeczno-demograficzne; kobiety; MŚP; przedsiębiorczość

Key words: entrepreneurship; social and demographic features; women; SME

\section{Wprowadzenie}

Z analizy najnowszych danych wynika, że Polska znajduje się na szóstym miejscu w Unii Europejskiej pod względem liczby osób mających własną firmę (35\%). Wartość ta oscyluje wokół średniej dla UE-27 i obejmuje łącznie osoby samozatrudnione i pracodawców. Jeszcze lepiej przedstawia się sytuacja dotycząca samych pracodawców. Według Eurostatu Polska sytuuje się na pierwszym miejscu w Europie pod względem udziału kobiet wśród pracodawców. Udział ten wynosi 29,4\%. Stosunkowo wysoka aktywność Polek w sferze przedsiębiorczości jest wypadkową dwóch czynników. Z jednej strony Polki czują się w istotnym stopniu współodpowiedzialne za byt ekonomiczny rodziny, co skłania je do podejmowania działalności gospodarczej. Są to, jak wynika z badań (Lisowska, 2004), tzw. czynniki wypychania do pracy na własny rachunek. Z drugiej strony pojawił się nowy motyw charakterystyczny dla krajów wysokorozwiniętych, gdzie kobiety szukają w biznesie wysokich dochodów i samorealizacji (Mizgajska, 2011). W tym wypadku mamy do czynienia z tzw. czynnikiem przyciągania.

Niniejszy artykuł odpowiada na następujące pytania badawcze:

1. Czy sposób zarządzania firmą przez kobiety i mężczyzn jest podobny, czy różny?

2. Jaki jest wpływ cech społeczno-demograficznych przedsiębiorstw prowadzonych przez kobiety i mężczyzn na sposób zarządzania firmą?

W artykule sprawdzono dwie hipotezy:

1. Sposób zarządzania przedsiębiorstwem przez kobiety i mężczyzn jest bardziej podobny niż zróżnicowany.

2. Na różnice w sposobie zarządzania wpływają cechy społeczno-demograficzne przedsiębiorców kobiet i mężczyzn.

Na podstawie wyników badań Zapalskiej (1997) oraz badań własnych (Mizgajska, 2008) przez sposób zarządzania rozumie się cele prowadzenia przedsiębiorstwa, przeznaczenie zysku oraz stopień korzystania z kredytów, aplikowanie i korzystanie ze środków UE oraz użycie Internetu w celu kupna i sprzedaży.

Cechy społeczno-demograficzne podzielono na czynniki związane z osobą właściciela/ właścicielki oraz związane z firmą. Czynniki związane z osobą właściciela/właścicielki to: edukacja, wiek i sytuacja rodzinna określona przez stan cywilny i liczbę dzieci. Natomiast cechy związane z firmą to: wielkość firmy, długość lat na rynku, wielkość miasta, w którym firma funkcjonuje, oraz prowadzenie firmy rodzinnej.

Poziom edukacji właściciela/właścicielki zmierzono przez stopień wykształcenia formalnego, udział w szkoleniach oraz doświadczenie zawodowe. Doświadczenie zawodowe dotyczy pracy 
zgodnej z wyuczonym zawodem, stażu pracy, zmiany pracodawcy i doświadczenia w kierowaniu przed założeniem własnej firmy.

W pracy wykorzystano materiał empiryczny zebrany w sposób celowy metodą ankietową ze 143 firm kierowanych przez kobiety oraz 158 firm kierowanych przez mężczyzn reprezentujących sektor małych i średnich przedsiębiorstw w Wielkopolsce. Materiał został zebrany za pomocą wywiadu bezpośredniego z przedsiębiorcą. Ankietyzacja przedsiębiorstw została przeprowadzona przez studentów I roku studiów magisterskich Uniwersytetu Ekonomicznego w Poznaniu w ramach zajęć z przedsięborczości wśród firm, które funkcjonują dłużej niż trzy lata na rynku. Badania były przeprowadzone w 2011 r., a informacje o firmach i sposobach zarządzania dotyczą lat 2007-2010.

Materiał badawczy przetworzony został następującymi metodami analizy porównawczej: test zgodności chi-kwadrat, test t-studenta oraz test Scheffe. Przy weryfikacji merytorycznej hipotez założony został poziom istotności $\alpha=0,05$.

Zarówno w grupie kobiet przedsiębiorców, jak i w grupie mężczyzn średni wiek wynosił 43 lata. Kobiety prowadzące własną działalność były bardzo dobrze wykształcone: w ich grupie większy był odsetek osób ze średnim wykształceniem niż w grupie mężczyzn (tab. 1). Jest to prawidłowość, którą potwierdzają wyniki poprzednich badań (Mizgajska, 2008; Demoskop, 2001). Także średnie dane dla roku 2011 zebrane przez GUS wskazują na podobny poziom wykształcenia przedsiębiorców.

Tab. 1. Poziom wykształcenia przedsiębiorców w 2010 r.

\begin{tabular}{|l|c|c|}
\hline \multirow{2}{*}{\multicolumn{1}{|c|}{ Poziom wykształcenia }} & Kobiety & Mężczyźni \\
\cline { 2 - 3 } & \multicolumn{2}{|c|}{ w \% } \\
\hline Wykształcenie podstawowe & - & 0,63 \\
\hline Wykształcenie zawodowe & 11,89 & 16,46 \\
\hline Wykształcenie średnie & 45,45 & 39,87 \\
\hline Wykształcenie wyższe & 42,66 & 43,04 \\
\hline
\end{tabular}

Źródło: opracowanie własne na podstawie badań przeprowadzonych w $2011 \mathrm{r}$.

Sytuacja rodzinna przeciętnego przedsiębiorcy, zarówno kobiety, jak i mężczyzny, jest podobna. Właściciel działalności gospodarczej zazwyczaj znajduje się w związku partnerskim lub małżeńskim. Gospodarstwo domowe, w którym żyją przedsiębiorcy, składa się przeciętnie z czterech osób, w którym wychowywana jest dwójka dzieci. Niepokojącym zjawiskiem jest pojawiający się z roku na rok większy udział kobiet przedsiębiorców, które deklarują opiekę jedynie nad jednym dzieckiem. Zatem odchodzenie od klasycznego modelu rodziny $2+2$ spotykane jest częściej w grupie kobiet do 30 roku życia. Powyższe dane zgodne są również z wynikami poprzednich sondaży (Lisowska, 2009; Mizgajska, 2008).

\section{Badany problem w literaturze}

W literaturze polskiej problem odrębności sposobów zarządzania przedsiębiorstwem przez kobiety i mężczyzn był podejmowany przez niewielu autorów. Badania typu gender zapoczątkowała Zapalska (1997). Autorka, w artykule opublikowanym w 1997 r. w anglojęzycznym periodyku, opisała motywacje, cele i przyczyny sukcesu prowadzenia małego przedsiębiorstwa 
przez kobiety i mężczyzn. Główną przyczyną sukcesu kobiet była ich kreatywność, a mężczyzn - niezależność. Badania Zapalskiej wykazały, że motywacje polskich kobiet-przedsiębiorców, ich osobista charakterystyka są podobne jak u mężczyzn prowadzących przedsiębiorstwa, nie różnią się też od motywacji zachodnich przedsiębiorców. Stylem zarządzania męskim i kobiecym zajmowała się Lisowska (2009). Lisowska analizowała kryteria dobrych szefów wśród polskich menedżerek oraz współzależność między autorytatywnym stylem kierowania a stopniem wykształcenia. Według jej badań stopień autorytatywności jest mniejszy u menedżerek mających lepsze wykształcenie. Z kolei Kupczyk (2009) diagnozowała czynniki sukcesów odnoszonych w zarządzaniu przez kobiety menedżerki. Według niej najważniejszy dla osiągnięcia sukcesu okazał się sposób zarządzania otwarty na zmiany, nastawiony na ludzi, proaktywny i przedsiębiorczy.

Dwie ostatnie prace dotyczą badań prowadzonych tylko wśród kobiet. Wpływem edukacji na sposób zarządzania zajmowała się wcześniej również współautorka niniejszego artykułu (Mizgajska, 2008). Zbadała ona wpływ wykształcenia i udziału w szkoleniach na sposób zarządzania firmą przez kobiety i mężczyzn w Wielkopolsce. Z jej opracowań dotyczących lat 2003-2006 wynikało, że sposób zarządzania firmą przez kobiety i mężczyzn był różny i zależał od stopnia wykształcenia oraz udziału w szkoleniach.

W literaturze anglojęzycznej od 30 lat pojawiają się prace dotyczące różnic i podobieństw w prowadzeniu firmy przez kobiety i mężczyzn. Dyskusja nad tym, czy mężczyźni i kobiety podobnie, czy różnie, prowadzą swoje przedsiębiorstwa zaczęła się w pierwszej połowie lat 80. XX w. Była ona połączona z tzw. feministyczną teorią i koncentrowała się na biologicznych różnicach wpływających na społeczne zachowanie obu płci. Według Barret i Mores (2009), badania nad przedsiębiorczością w tamym czasie dotyczyły odpowiedzi na pytania, czy i o ile przedsiębiorczość kobiet jest różna od przedsiębiorczości mężczyzn. Na początku lat 80. badano różnice w zakładaniu firm przez kobiety i przez mężczyzn (Belcourt, 1987; Birley, 1989). Następnie badano, czy i jak się różni sposób zarządzania kobiet od sposobu zarządzania mężczyzn (Chaganti, 1986; Folker, Sorenson, 2000). Sprawdzano też, czy kobiety bardziej się obawiają ponoszenia ryzyka niż mężczyźni (J.A.C. Carland, J.W. Carland, 1991), czy mniej od nich są zainteresowane wzrostem firmy (Hisrich, 1986) i czy są bardziej niż mężczyźni zainteresowane dopasowaniem ich biznesów do stylu życia (Hisrich, Brush, 1983).

Część autorów uważa, że pod względem sposobów zarządzania przedsiębiorstwem kobiety i mężczyźni się różnią. Rosener $(1997,1999)$ wprowadziła pojęcie męskiego i kobiecego stylu zarządzania. Według niej mężczyźni reprezentują transakcyjny (transactional) styl zarządzania, nagradzając lub karząc za dobre lub złe wyniki. Natomiast kobiety reprezentują transformational leadership. Oznacza to, że kładą nacisk na motywację pracowników do osiągania celów i zachęcają ich do uczestniczenia w podejmowaniu decyzji i w zarządzania przez jakość, a nie piastowane stanowisko. Grant (1988) zauważył, że kobiety menedżerowie charakteryzują się takimi cechami, jak: komunikatywność, kooperacja, przynależność, przywiązanie i zażyłość. Z kolei Eagly i Johnson (1990) ustalili, że kobiety reprezentują bardziej partycypujący styl w zarządzaniu, a mężczyźni - styl autokratywny. Również badania Rozier i Hersh-Cochran (1996) potwierdziły tę tendencję. Styl partycypujący zarządzania był bardzo popularny w latach 90. XX w. Charakteryzował się on konsultowaniem się z osobami zarządzającymi przed podjęciem decyzji. Natomiast jeżeli brakuje konsultacji i delegowania zadań, to mówi się o stylu autokratywnym. Gibson w 1995 r. stwierdził, że te różnice wynikają z odgrywania roli społecznej i jednostkowej. Społeczna rola w zarządzaniu polega na koncentrowaniu się na podniesieniu zamożności, a wymiar jednostkowy - na ukierunkowaniu na 
zadania i kontrolę. Według Gibsona (2005), mężczyźni chętniej skupiają się na zadaniach, a kobiety - na wzajemnych ułatwieniach. Kobiety menedżerowie w porównaniu z mężczyznami menadżerami są bardziej ukierunkowane na zrozumienie, budowanie zespołu, rozwijanie interpersonalnych umiejętności, demokratyczne wartości i komunikację. Zdaniem Chapman (1975), w strategii kobiety bardziej kładą nacisk na wzajemne stosunki niż na zwycięstwo. Te cechy wskazują na tzw. kobiece umiejętności. Również wyniki badań Muchtar (2002) potwierdzają różnicę między sposobem zarządzania przedsiębiorstwem przez kobiety i mężczyzn. Różnica ta dotyczy stylu zarządzania, natury struktury organizacji, stopnia delegowania zadań, sposobu ustalania strategicznych celów oraz wpływu osobistych celów na proces podejmowania decyzji.

Niektórzy autorzy uważają, że kobiecy styl zarządznia nie istnieje. Ich zdaniem nie ma różnicy lub są małe różnice między sposobem zarządzania kobiet i mężczyzn. Według badań Dobbinsa i Platza (1986), kobiety i mężczyźni mają podobny styl zarządzania. Wyniki te potwierdził Grant (1988), który dodał również, że różnice są, ale pomiędzy kobietami-przedsiębiorcami i wśród mężczyzn. Z kolei Oshagbemi i Gill (2003), prowadzący badania w Wielkiej Brytanii, potwierdzili tezę, że nie ma różnicy w dyrektywnym, konsultacyjnym i partycypującym stylu zarządzania wśród kobiet i mężczyzn, ponieważ zarówno kobiety, jak i mężczyźni mogą reprezentować oba style zarządzania.

\section{Sposób zarządzania przedsiębiorstwem przez kobiety i mężczyzn}

Pytanie badawcze postawione w niniejszym artykule brzmi: Czy sposób zarządzania przez kobiety i mężczyzn w Polsce jest podobny, czy różny?

Według badań Zapalskiej z 1997 r., inne były cele prowadzenia biznesu przez kobiety i mężczyzn. Kobiety były bardziej zainteresowane osiąganiem zysków w długim okresie czasu, a mężczyźni - w krótkim. Ponadto więcej kobiet deklarowało przeznaczenie zysku na zwiększenie obrotów, a mężczyźni chcieli przeznaczyć zysk na konsumpcję.

W badaniach własnych (Mizgajska, 2011) przeprowadzonych w 2011 r. w Wielkopolsce spośród 12 wymienionych czynników decydujących o sposobie zarządzania tylko 4 istotnie różniły się w badanych grupach przedsiębiorców. Różnice dotyczyły celu prowadzenia firmy, jakim jest osobista satysfakcja i przeznaczenie zysku na konsumpcję. Kobiety znacznie częściej zaznaczały jako istotny cel działalności osobistą satysfakcję (kobiety: 60,84\%; mężczyźni: 49,37\%) i przeznaczenie zysku na konsumpcję (kobiety: 41,26\%; mężczyźni: 27,85\%). Mężczyźni za ważny cel działalności uznali wzrost firmy (mężczyźni: 63,92\%, kobiety: 43,36\%). Ponadto częściej opowiedzieli się za użyciem Internetu w celach sprzedaży i zakupu (mężczyźni: 50,63\%; kobiety: 34,97\%). Rozkład pozostałych czynników w badanych grupach był podobny. Oznacza to, że sposób zarządzania kobiet i mężczyzn w Polsce jest bardziej podobny niż zróżnicowany (tab. 2).

Kobiety prowadzące firmę, mające wyższe i średnie wykształcenie, opowiedziały się za wzrostem firmy, natomiast kobiety z wykształceniem zawodowym - za osobistą satysfakcją. U mężczyzn im wyższy był ich poziom edukacji, tym większe było ich zainteresowanie wzrostem firmy i osiąganiem celów w długim okresie czasu.

Wyniki te są różne od wyników badań uzyskanych 15 lat temu przez Zapalską (1997).

Wyniki przeprowadzonych badań dowodzą, że sposób zarządzania własną firmą przez kobiety i mężczyzn w Polsce w ostatnich 15 latach się zmienił. Na skutek dostępu do szkoleń, większych doświadczeń zawodowych, różnica między sposobem zarządzania własnym przedsiębiorstwem przez kobiety i mężczyzn się zmniejszyła. 
Tab. 2. Zestawienie czynników kształtujących sposób zarządzania wśród kobiet oraz mężczyzn w 2010 r.

\begin{tabular}{|l|c|c|c|c|c|}
\hline \multirow{2}{*}{$\begin{array}{c}\text { Elementy } \\
\text { sposobu zarządzania firmą }\end{array}$} & \multicolumn{2}{c|}{ Kobiety } & \multicolumn{2}{c|}{ Mężczyźni } & \multirow{2}{*}{ P } \\
\cline { 2 - 5 } & takie & tak & nie & \\
\hline $\begin{array}{l}\text { Celem firmy jest osiąganie zysków } \\
\text { w długim okresie czasu }\end{array}$ & $65,73 \%$ & $34,27 \%$ & $69,62 \%$ & $30,38 \%$ & $\mathrm{p}=0,47$ \\
\hline $\begin{array}{l}\text { Celem firmy jest osiąganie zysków } \\
\text { w krótkim okresie czasu }\end{array}$ & $21,68 \%$ & $78,32 \%$ & $20,25 \%$ & $79,75 \%$ & $\mathrm{p}=0,76$ \\
\hline Celem jest wzrost firmy & $43,36 \%$ & $56,64 \%$ & $63,92 \%$ & $36,08 \%$ & $\mathrm{p}=0,00$ \\
\hline Celem jest osobista satysfakcja & $60,84 \%$ & $39,16 \%$ & $49,37 \%$ & $50,63 \%$ & $\mathrm{p}=0,05$ \\
\hline $\begin{array}{l}\text { Zysk jest przeznaczany na zwiększanie } \\
\text { obrotów }\end{array}$ & $34,97 \%$ & $65,03 \%$ & $28,48 \%$ & $71,52 \%$ & $\mathrm{p}=0,27$ \\
\hline $\begin{array}{l}\text { Zysk jest przeznaczany na kupno } \\
\text { środków trwałych }\end{array}$ & $17,48 \%$ & $82,52 \%$ & $22,78 \%$ & $77,22 \%$ & $\mathrm{p}=0,25$ \\
\hline $\begin{array}{l}\text { Zysk jest przeznaczany na inwestycje } \\
\text { poza firmą }\end{array}$ & $13,99 \%$ & $86,01 \%$ & $16,46 \%$ & $83,54 \%$ & $\mathrm{p}=0,55$ \\
\hline Zysk jest przeznaczany na konsumpcję & $41,26 \%$ & $58,74 \%$ & $27,85 \%$ & $72,15 \%$ & $\mathrm{p}=0,01$ \\
\hline $\begin{array}{l}\text { Czy firma ubiegała się o dofinansowa- } \\
\text { nie z UE? }\end{array}$ & $8,39 \%$ & $91,61 \%$ & $11,39 \%$ & $88,61 \%$ & $\mathrm{p}=0,38$ \\
\hline Czy firma otrzymała dofinansowanie? & $58,33 \%$ & $41,67 \%$ & $47,37 \%$ & $52,63 \%$ & $\mathrm{p}=0,55$ \\
\hline $\begin{array}{l}\text { Czy firma korzystała w ciągu ostatnich } \\
\text { trzech lat z kredytów? }\end{array}$ & $32,17 \%$ & $67,83 \%$ & $41,77 \%$ & $58,23 \%$ & $\mathrm{p}=0,08$ \\
\hline $\begin{array}{l}\text { Firma używa Internetu w celu zakupów } \\
\text { i sprzedaży }\end{array}$ & $34,97 \%$ & $65,03 \%$ & $50,63 \%$ & $49,37 \%$ & $\mathrm{p}=0,01$ \\
\hline Zysk jest przeznaczany na konsumpcję & $41,26 \%$ & $58,74 \%$ & $27,85 \%$ & $72,15 \%$ & $\mathrm{p}=0,01$ \\
\hline
\end{tabular}

Źródło: opracowanie własne na podstawie badań przeprowadzonych w 2011 r.

\section{Wpływ cech społeczno-demograficznych związanych z osobą właścicielki/właściciela na sposób zarządzania firmą}

Cechy społeczno-demograficzne związane z osobą właściciela/właścicielki zostały pogrupowane na związane z edukacją, wiekiem i sytuacją rodzinną. Poziom edukacji zmierzono za pomocą stopnia wykształcenia formalnego, udziału w szkoleniach oraz doświadczenia zawodowego. Stopień wykształcenia formalnego określono przez liczbę osób z wykształceniem podstawowym, zawodowym, średnim i wyższym. Natomiast udział w szkoleniach zmierzono za pomocą liczby przebytych szkoleń w ciągu ostatnich trzech lat. Z kolei doświadczenie zawodowe dotyczyło pracy zgodnej z wyuczonym zawodem (tak lub nie), stażu pracy (zmierzonego liczbą przepracowanych lat), zmiany pracodawcy zmierzonej liczbą zmienionych miejsc pracy przed założeniem własnej firmy oraz doświadczeniem na stanowisku kierowniczym przed założeniem własnej firmy (tak lub nie).

Inne mierniki to wiek właściciela/właścicielki oraz sytuacja rodzinna scharakteryzowana przez: liczbę osób w rodzinie, łącznie z liczbą dzieci niepracujących, aktywność zawodową 
partnera (czy pracuje w tej samej firmie, czy jest na emeryturze, czy pobiera rentę lub nie pracuje) oraz czas poświęcony rodzinie po założeniu przedsiębiorstwa. Pytanie dotyczyło zmniejszenia czasu poświęconego rodzinie po założeniu firmy. Każdą z tych cech, opisaną za pomocą wymienionych mierników, skorelowano z elementami sposobu zarządzania. Elementy sposobu zarządzania własną firmą zostały określone przez cele prowadzonej firmy, przeznaczenie zysku, korzystanie ze środków UE, kredytów i zastosowanie Internetu. Elementy sposobu zarządzania zostały przedstawione w główce tab. 2.

Ze względu na dużą liczbę użytych mierników za pomocą cech niemierzalnych ocenę współzależności przeprowadzono w formie testu zgodności chi-kwadrat, testu t-studenta oraz testu Scheffe - osobno dla grupy kobiet i grupy mężczyzn.

Duża liczba zbadanych związków przy pomocy trzech testów i wynikający z tego bardzo obszerny materiał statystyczny spowodowały, że wyniki badanych współzależności przedstawiono w formie syntetycznej, podając podsumowania współzależności. Omówiono tylko te wyniki, które okazały się istotne wg jednego z użytych testów.

Z przeprowadzonych badań w grupie kobiet wynika, że im wyższy stopień wykształcenia, tym kobiety częściej posługują się Internetem w celu zakupu i sprzedaży oraz korzystają z kredytów jako formy zewnętrznego finansowania własnej działalności. Kobiety, które prowadziły transakcje kupna oraz sprzedaży przez Internet, były dobrze wykształcone (średnie wykształcenie miało 32,3\% respondentek, a wyższe - 44,2\%). Kobiety rzadziej niż mężczyźni korzystały z kredytów (kobiety 32\%, a mężczyźni - 41,77\%), ale te, które korzystały, były dobrze wykształcone: aż 93,4\% spośród nich miało wykształcenie średnie lub wyższe. Korzystanie z kredytów jako zewnętrznego źródła finansowania było przedmiotem wielu badań. Badania Marlow i Patton (2005) wskazują, że kobiety rzadziej korzystają z kredytów jako zewnętrznego źródła finansowania aniżeli mężczyźni. Procedury udzielania kredytu przez banki często dyskryminują kobiety (Fay, Williams, 1991, 1993; Martin, Wright, 2005). Uważa się, że przyjęte przez banki procedury preferują męskie normy, takie jak osobiste oszczędności, długość kariery zawodowej czy lokalne uwarunkowana (Moore, Buttner, 1997; Carter, Rosa, 1998). Wyniki badań respondentek z Wielkopolski potwierdzają te tendencje.

Z kolei w grupie mężczyzn przedsiębiorców im niższy był stopień wykształcenia, tym częściej pojawiała się deklaracja, że celem firmy było osiąganie zysków w krótkim czasie. Cel ten był istotny dla przedsiębiorców z zawodowym i średnim wykształceniem. Osiąganie zysków w krótkim czasie jest celem, który częściej jest łączony z męskim sposobem zarządzania. Wyniki te również zostały potwierdzone w badaniach Zapalskiej (1997).

Następny czynnik to udział w szkoleniach, odzwierciedlony w liczbie dni, które przedsiębiorcy poświęcali na różne typy szkoleń w ciągu badanych trzech lat. Kobiety przedsiębiorcy, które w badanych latach więcej dni przeznaczały na szkolenia, zaznaczały częściej niż pozostałe, że zysk przeznaczany jest na kupno środków trwałych. Z kolei dla kobiet, które rzadziej brały udział w szkoleniach, ważnym celem działalności był zysk przeznaczany na konsumpcję - aż 41,25\% pań zaznaczyło ten czynnik jako ważny. W grupie mężczyzn czynnik ten był istotnie statystycznie związany z ubieganiem się o środki UE i korzystaniem z kredytów. Przedsiębiorcy, którzy ubiegali się o dofinansowanie z UE, spędzili średnio więcej o 22 dni na szkoleniach niż przedsiębiorcy, którzy nie starali się o dofinansowanie. Również z kredytów częściej korzystali przedsiębiorcy - mężczyźni, którzy spędzili w badanym okresie średnio więcej dni na szkoleniach (średnio 20 dni).

Wyższy udział w szkoleniach zarówno dla kobiet, jak i dla mężczyzn ma przełożenie na bardziej kompetentny sposób zarządzania firmą. Wyniki badań wyraźnie wskazują, że kobiety korzystające często ze szkoleń inwestują w środki trwałe. Również mężczyźni biorący udział 
w szkoleniach częściej korzystali z dodatkowego źródła finansowania, jakim był kredyt, niż mężczyźni, którzy nie brali udziału w szkoleniach.

Następna istotna współzależność dotyczy związku między doświadczeniem zawodowym określonym przez obecną pracę zgodną z wyuczonym zawodem a sposobem zarządzania firmą. Do ciekawych należy fakt, że dla kobiet, które nie prowadziły firmy zgodnie z wyuczonym zawodem, celem był wzrost firmy (58,06\% kobiet wybrało ten czynnik). Natomiast większość $(65,33 \%)$ kobiet, które prowadziły własną firmę zgodnie z wyuczonym zawodem, nie zaliczała tego czynnika do trzech najistotniejszych celów prowadzenia własnej działalności. Z kolei mężczyźni, którzy nie prowadzili firmy zgodnie z wyuczonym zawodem, zaznaczali, że zysk jest przeznaczany na zwiększanie obrotu (40,51\%). Zmiana zawodu przed założeniem firmy zarówno przez kobiety, jak i przez mężczyzn była związana z ambitnie deklarowanym celem prowadzenia firmy i przeznaczeniem zysku. Natomiast zupełnie inny był wpływ częstotliwości zmian pracy przed założeniem własnej firmy na cele prowadzenia firmy. Kobiety przedsiębiorcy, które częściej zmieniały pracę przed założeniem własnej firmy, zaznaczały częściej, że zysk jest przeznaczany na konsumpcję. Tymczasem dla kobiet, które rzadziej zmieniały pracę, głównym celem był wzrost firmy. Kobiety, które z różnych przyczyn częściej zmieniały miejsca pracy przed założeniem własnej firmy, ograniczały się do zapewnienia źródła utrzymania a nie inwestycji w firmę. Takiej zależności nie stwierdzono wśród mężczyzn przedsiębiorców.

Przedmiotem dalszych badań był związek między wiekiem właścicielek i właścicieli oraz ich sytuacją rodzinną a elementami sposobów zarządzania firmą. Wiek przedsiębiorcy - zarówno kobiet, jak i mężczyzn - nie był skorelowany z elementami sposobu zarządzania.

Sytuacja rodzinna została scharakteryzowana przez liczbę osób w rodzinie, łącznie z liczbą dzieci niepracujących, przez aktywność zawodową partnera oraz czas poświęcony rodzinie po założeniu przedsiębiorstwa. Spośród wymienionych cech badanie wykazało tylko istotny związek statystyczny w grupie firm prowadzonych przez kobiety między czasem poświęconym rodzinie a celem prowadzenia firmy. Dla kobiet, które po założeniu firmy poświęcały tyle samo czasu rodzinie, jak przed założeniem działalności, najważniejszym celem prowadzenia firmy była własna satysfakcja (73,5\%). Dominującą tendencją w tej grupie kobiet było przeznaczenie zysku na konsumpcję (56,6\%). Natomiast w grupie kobiet poświęcającej mniej czasu rodzinie po założeniu własnego biznesu najważniejszym celem było osiąganie zysku w długim okresie czasu (73,3\%). Stąd można wnioskować, że kobiety poświęcające więcej czasu rodzinie były nakierowane na zapewnienie źródła utrzymania. Być może, bardziej ambitne cele prowadzenia firmy realizują kobiety kosztem czasu poświęconego rodzinie.

\section{Wpływ cech związanych z firmą na sposób zarządzania przez kobiety i mężczyzn}

Do cech związanych z firmą należą: wielkość firmy mierzona liczbą zatrudnionych, długość trwania firmy na rynku mierzona za pomocą liczby lat, wielkość miasta, w którym firma funkcjonuje mierzona liczbą mieszkańców oraz fakt prowadzenia firmy rodzinnej.

Spośród badanych cech liczba zatrudnionych, prowadzenie firmy rodzinnej oraz wielkość ośrodka miejskiego, w którym firma funkcjonuje, mają statystycznie istotny wpływ na sposób zarządzania firmą. Kobiety przedsiębiorcy, które używały Internetu do sprzedaży i zakupu, oraz te, które przeznaczały zysk na zwiększenie obrotów, zatrudniały średnio osiem osób więcej aniżeli pozostałe właścicielki. Im firma była większa, tym częściej kobiety korzystały z Internetu w celu sprzedaży i zakupu oraz przeznaczały zysk na zwiększenie obrotów. Z kolei mężczyźni przedsiębiorcy zatrudniający mniej niż trzy osoby przeznaczali zysk na konsumpcję.

Mężczyźni zakładający firmy w większych miejscowościach (powyżej 80 tys. mieszkańców) częściej używali Internetu do sprzedaży i zakupu niż mężczyźni mieszkający w mniejszych 
miejscowościach (72,5\% właścicieli w miastach powyżej 80 tys. mieszkańców i 43,22\% przedsiębiorców z miast poniżej 80 tys. mieszkańców). Również przedsiębiorcy z mniejszych miast rzadziej aplikowali o środki UE aniżeli przedsiębiorcy z większych miast. Przedsiębiorcy z większych miast mają lepszy dostęp do informacji o środkach pomocowych.

Następną cechą istotnie współzależną z celem firmy jest prowadzenie firmy rodzinnej. Cecha ta jest ważna tylko w grupie przedsiębiorstw prowadzonych przez mężczyzn. Aż 82,93\% mężczyzn, którzy prowadzili firmę rodzinną, jako główny cel działalności deklarowało osiąganie zysków w długim okresie czasu.

\section{Wnioski z badań i rekomendacje}

Badania dotyczące wpływu wybranych cech społeczno-demograficznych na sposób zarządzania firmą przez kobiety i mężczyzn w Wielkopolsce wskazały na następujące prawidłowości:

- Sposób zarządzania firmą przez kobiety i mężczyzn był bardziej podobny niż zróżnicowany.

- Inne cechy społeczno-demograficzne wpływały na sposób zarządzania firmą przez kobiety i mężczyzn.

- Im wyższy był poziom wykształcenia kobiet, tym częściej używały one Internetu do kupna i sprzedaży oraz częściej korzystały z kredytów.

- Mężczyźni z wykształceniem średnim i zawodowym za główny cel prowadzenia firmy uważali uzyskanie zysków w krótkim czasie.

- Kobiety, które często brały udział w szkoleniach, częściej przeznaczały zysk na kupno środków trwałych niż kobiety, które rzadko uczestniczyły w szkoleniach.

- Kobiety rzadziej korzystające ze szkoleń częściej deklarowały przeznaczenie zysku na konsumpcję.

- Mężczyźni biorący udział w szkoleniach częściej korzystali z kredytów niż mężczyźni, którzy nie brali udziału w szkoleniach.

- Zmiana zawodu, przekwalifikowanie się w związku z założeniem firmy nie miały negatywnego wpływu na deklarowany cel prowadzenia firmy przez kobiety i mężczyzn.

- Ujemny wpływ na deklarowany cel prowadzenia firmy przez kobiety miała częstotliwość zmian pracy przed założeniem własnej firmy.

- Czas poświęcony rodzinie przez kobiety po założeniu własnej firmy wpływał na przeznaczenie zysku.

- Kobiety, które poświęcały tyle samo czasu rodzinie przed i po założeniu firmy, deklarowały częściej jako cel własną satysfakcję i przeznaczenie zysku na konsumpcję.

- Kobiety, które mniej czasu poświęcały rodzinie po założeniu firmy, za cel uważały osiąganie zysku w długim okresie czasu.

- Mężczyźni zakładający firmy w dużych miastach częściej używali Internetu w celu kupna i sprzedaży oraz częściej aplikowali o środki UE niż mężczyźni z mniejszych miejscowości.

- Im większa była firma prowadzona przez kobiety, tym więcej z nich używało Internetu do kupna i sprzedaży, i przeznaczało zysk na zwiększenie obrotu.

- W przypadku mężczyzn im mniejsza była firma, tym częściej właściciele deklarowali przeznaczenie zysku na konsumpcję.

- Celem firm rodzinnych prowadzonych przez mężczyzn było osiąganie zysku w długim okresie czasu.

Wyniki badań nie potwierdziły wyników uzyskanych przez Zapalską (1997) 15 lat temu, według których sposób zarządzania firmą przez kobiety i mężczyzn jest istotnie różny.

Pewne odrębności w sposobie zarządzania dotyczą stopnia korzystania z kredytów oraz korzystania z Internetu w celach zakupu lub sprzedaży. Wyniki niniejszych badań potwierdziły 
wyniki badań Marlow, Patton (2005), według których kobiety rzadziej korzystały z kredytów jako zewnętrznego źródła finansowania. Niechęć do korzystania z kredytów przez kobiety może być powiązana z większą odpowiedzialnością i obawą o ich spłatę w niekorzystnej sytuacji finansowej. Natomiast główne różnice w sposobie zarządzania wynikają z cech społeczno-demograficznych obu grup przedsiębiorców. Lepsze wykształcenie formalne oraz większy udział w szkoleniach zarówno kobiet, jak i mężczyzn wpływał na częstsze korzystanie z kredytu jako źródła finansowania, a także na wykorzystanie Internetu w celach zakupu i sprzedaży. Natomiast inne cechy były istotne dla kobiet, a inne - dla mężczyzn. Dla kobiet liczył się czas poświęcony rodzinie po założeniu firmy. Kobiety, które tyle samo czasu poświęcały rodzinie po założeniu firmy, częściej deklarowały przeznaczenie zysku na konsumpcję. Kobiety, które mniej czasu poświęcały rodzinie, częściej wskazywały na przeznaczenie zysku na zakup środków trwałych, czyli częściej inwestowały w firmę. Z kolei w wypadku mężczyzn fakt prowadzenia firmy rodzinnej był istotnie powiązany $\mathrm{z}$ celem osiągania zysku $\mathrm{w}$ długim okresie czasu, co wynika z przyjętych długookresowych planów rozwoju własnej firmy i chęci zatrzymania firmy w rękach rodziny. Również tylko mężczyźni przedsiębiorcy z większych miast częściej korzystali z Internetu w celu zakupu i sprzedaży.

Duża zmienność uwarunkowań zewnętrznych związanych z kryzysem wiąże się z coraz większym ryzykiem prowadzenia własnego, zwłaszcza małego, przedsiębiorstwa. Jak wykazały wyniki badań, udział w szkoleniach z zakresu zarządzania pozwala na trafniejszy wybór celu prowadzenia firmy. Uzyskane wyniki badań potwierdzają konieczność budowania kompetencji przedsiębiorców. Wyniki te są adresowanie do instytucji wspierających biznes. Liczne instytucje z tzw. otoczenia biznesu powinny być bardziej zaangażowane w przygotowywanie oferty bezpłatnych lub częściowo odpłatnych szkoleń i warsztatów dających praktyczną wiedzę z zakresu prowadzenia przedsiębiorstwa i zarządzania nim, a także korzystania z różnych form finansowania oraz korzystania z Internetu. Bardzo ważne jest upowszechnienie szkoleń typu on-line, pod opieką mentora, za które powinna być odpowiedzialna np. Polska Agencja Rozwoju Przedsiębiorczości. Duże znaczenie ma upowszechnienie dostępu do szerokopasmowego Internetu w małych miejscowościach, gdyż Internet staje się kluczowym mechanizmem w rozwoju firm. Proponuje się przeprowadzenie akcji informacyjnej skierowanej w szczególności do władz samorządowych i lokalnych w tych częściach Polski, gdzie nadal występuje problem braku dostępu do Internetu. Równie ważna jest zachęta do korzystania ze środków UE dostępnych w ramach obecnej i przyszłej perspektywy.

\section{Literatura \\ References}

Chapman, B. (1975). Comparison of male and female leadership styles, Academy of Management Journal, 18, No 3, 645-651.

Barrett, M., Moores, K. (2009). Women in family business leadership roles, Daughters on the stage, Cheltenham: Edward Elgar Publishing.

Belcourt, M. (1987). Sociological Factors Associated with Female Entrepreneurship, Journal of Small Business and Entrepreneurship, 21(3), 22-31.

Birley, S. (1989). Female entrepreneurs: are they really any different?, Journal of Small Business Management, 27(1), 32-37. 
Chaganti, R. (1986). Management in women-owned Enterprises, Journal of Small Business Management, 24(4), 18-29.

Carland, J.A.C., Carland, J.W. (1991). Managers, small business owners and entrepreneurs: the cognitive dimension, Journal of Business and Entrepreneurship, 4 (2), 55-62.

Dobbins, GH, Platz, S.J. (1986). Sex - differences in leadership - how real are they?, Academy of Management Review, 11, 118-134.

Carter, S., Rosa, P. (1998). The financing of male and female owned-businesses, Entrepreneurship and Regional Development, 10 (3), No 3, 225-241.

Eagly, A.,H, Johnson, B.T. (1990). Gender and leadership style: a meta-analysis, Psychological Bulletin, $117,125-145$.

Fay, M., Williams, L. (1991). Sex of applicants and the availability of business 'start-up' finance, Australian Journal of Management, 16(1), No 1, 65-72.

Fay, M., Williams, L. (1993). Gender bias and the availability of business loan, Journal of Business Venturing, 8(4), No 4, 363-376.

Folker, C.A, Sorenson, R.L. (2000). Women's orientation to management: An empirical revisit to gender differences using family business owners', paper presented at the Western Academy of management, Hawaii.

Gibson, C. (1995). An investigation of gender differences in leadership across four countries, Journal of International Business Studies, 26 (2), No 2, 225- 279.

Grant, J. (1988). Women as managers: what they can offer to organizations, Organizational Dynamics, 16(3), No 3, 56-63.

Hisrich, R.D. (1986). The Women Entrepreneur - Characteristics, Skills, Problems, and Prescription for Succes. W: D.L. Sexton., R.W. Smilor (ed.), The Art. And Science of Entrepreunership. Cambridge: Ballinger Publishing Company, 61-84.

Hisrich, R.D., Brush, C.G. (1983). The women entrepreneur: Implication of family, educational and occupational experience. W: J.A. Hornaday, J.A. Timmons, K.H. Wesper (ed.), Frontiers of Entrepreneurial Research, Boston, MA: Babson College, 566-587.

Kupczyk, T. (2009). Kobiety w zarządzaniu i czynniki ich sukcesów, Wrocław: Wyższa Szkoła Handlowa. Lisowska, E. (2009). Kobiecy styl zarzadzania, Gliwice: Wydawnictwo Helion.

Lisowska, E. (2004). Przedsiębiorczość kobiet w Polsce, W: B. Kożuch (red.), Przedsiębiorczość kobiet - wyzwanie XXI wieku. Białystok: Wydawnictwo Uniwersytetu w Białymstoku.

Martin, L., Wright, L. (2005). No gender in cyberspace? Empowering entrepreneurship and innovation in female-run ICT small firms, International Journal of Entrepreneurial Behavior and Research, 11(2), No. 2, 162-78.

Marlow, S., Patton, D. ( 2005). All credit to men? Entrepreneurship, finance, and gender, Entrepreneurship Theory and Practice, 29(6), No 6, 717-735.

Moore, D.P., Buttner, E.H. (1997). Women entrepreneurs: Moving Beyond the Glass Ceiling. Thousand Oaks, CA: Sage.

Mizgajska, H. (2008). Specyfika sposobu zarządzania przedsiębiorstwem przez kobiety na przykładzie Wielkopolski, Organizacja i Kierowanie, 3, 83-93.

Mizgajska, H. (2011). Kwalifikacje jako czynnik przedsiębiorczości kobiet i rozwoju firm. W: H. Mizgajska (red.), Przedsiębiorczość i rozwój firm. Poznań: Wydawnictwo UEP, 28-44.

Muchtar, S.M. (2002). Differences in Male and Female Management Characteristics: A Study of Owner - Manager Businesses, Small Business Economics, 18, 289-311.

OECD Factbook 2011-2012. Pozyskano z: http://www.oecd-ilibrary.org/economics/oecd-factbook-2011-2012_factbook-2011-en (data odczytu: 29.05.2013).

Oshagbemi, T., Gill, R. (2003). Gender differences and similarities in the leadership style and behaviour of UK managers, Women in Management Review, 18(6), No 6, 288-298.

Rosener, J., (1997). Leadership and the Paradox of Gender, W: M.R. Walsh (ed.), Women, Men, and Gender, Yale University Press.

Rosener, J. (1999). Different Genders, Different Styles, Los Angeles Business Journal, March 1, 14. 
Rozier, C.K., Hersh-Cochran, M.S. (1996). Gender differences in managerial characteristics in a female-dominated health profession, The Health Care Supervisor, June, 14(4), 57-70.

Zapalska, A. (1997). A profile of women entrepreneurs in Poland, Journal of Small Business Management, 35, No 4, 76-81.

Hanna Mizgajska, dr hab. inż., prof. nadzw. Uniwersytetu Ekonomicznego w Poznaniu.

Hanna Mizgajska jest autorką 105 publikacji, głównie z zakresu ekonomiki i funkcjonowania małych i średnich przedsiębiorstw (MŚP), w tym trzech monografii. Szczególne miejsce w jej dorobku zajmuje 19 anglojęzycznych publikacji w recenzowanych i objętych procedurą kwalifikacyjną materiałach z europejskich i światowych konferencji dotyczących small biznesu. Spośród nich 14 wiąże się z konferencjami organizowanych przez European Foundation for Management Development (EFMD), a 4 zawarte są w materiałach z konferencji organizowanych przez International Council for Small Business (ICSB). Główne zainteresowania badawcze to aktywność innowacyjna MŚP, wspieranie MŚP oraz przedsiębiorczość kobiet. Od 2005 r. autorka jest przewodniczącą Okręgowej Olimpiady Przedsiębiorczości przy Uniwersytecie Ekonomicznym w Poznaniu.

Hanna Mizgajska, PhD Eng., Extraordinary professor, Poznan University of Economics.

Hanna Mizgajska is an author of 105 publications, mainly about economics and the functioning of SME, three of which are monographs. Niniteen English publications play an important role in her scientific work as they were reviewed and accepted for qualificacation procedures in European and World Conferences on small business. Fourteen of the papers are connected with conferences organised by the European Foundation for Management Development (EFMD), and four are in conference materials organised by the International Council for Small Business (ICSB). Her research areas include SME innovation activitiy, supporting and developing SME and woman enterpreneurship. Since 2005 the author has been the President of the Regional Entrepreneurship Olympiad held by the Poznań University of Economics.

Dorota Płóciennik, mgr, doktorantka Uniwersytetu Ekonomicznego w Poznaniu.

Dorota Płóciennik przygotowuje pracę doktorską pt. Uwarunkowania prowadzenia firm internetowych przez kobiety w Polsce pod kierunkiem dr hab. inż. Hanny Mizgajskiej.

Dorota Płóciennik,MA, Poznan University of Economics.

The author is currently writing her doctor's thesis about "Conditions for running internet firms by women in Poland" under the guidance of Professor Hanna Mizgajska.

Adres/Address: Uniwersytet Ekonomiczny w Poznaniu

Al. Niepodległości 10

61-875 Poznań, Polska

e-mail: h.mizgajska@ue.poznan.pl 